\section{Kastamonu Eğitim Dergisi Kastamonu Education Journal}

Kasım 2019 Cilt:27 Sayı:6

kefdergi.kastamonu.edu.tr
Başvuru Tarihi/Received: 19.11.2018

Kabul Tarihi/Accepted: 15.02.2019

DOI: $10.24106 /$ kefdergi.3432

\title{
Yaşam Temelli Öğretim Yaklaşımına Dayalı 5E Modeli Kullanımının Öğretmen Adaylarının Ölçme Değerlendirme Dersine Yönelik Tutum ve Özyeterlik Algıları Üzerine Etkisinin İncelenmesi
}

\section{An Investigation of the Effects of 5E Model Based on Context-Based Instruction Approach on the Attitudes and Perception of Self-Efficacy of Pre-Service Teachers towards the Assessment and Evaluation Course}

\section{Öz}

\author{
Hülya DEDE ${ }^{1}$
}

$\mathrm{Bu}$ araştırmanın amacı, yaşam temelli öğretim yaklaşımına dayalı 5E modelinin öğretmen adaylarının ölçme değerlendirme dersine karşı tutum ve öz yeterlik algıları üzerindeki etkisini belirlemektir. Bu amaçla ölçme-değerlendirme dersi konularına uygun bağlamlar hazırlanmış ve yaşam temelli öğretim yaklaşımına dayalı $5 \mathrm{E}$ modeline uygun olarak dersler işlenmiştir. Çalışma grubunu 2017-2018 Öğretim yılı, bahar yarıyılında Kilis 7 Aralık Üniversitesi fen bilgisi öğretmenliği bölümü, 3. sınıfinda öğrenim gören 30 öğrenci oluşturmaktadır. Çalışmada araştırma yöntemi olarak tek grup ön test son test zayıf deneysel desen kullanılmıştır. Uygulama yaklaşık dört hafta sürmüştür. Veri toplama aracı olarak Eğitimde Ölçme ve Değerlendirme Dersine Yönelik Tutum Ölçeği ve Eğitimde Ölçme ve Değerlendirmeye Yönelik Özyeterlik Algısı Ölçeği kullanılmıştır. Elde edilen veriler bağımlı gruplar $t$ testi ile analiz edilmiştir. Çalışmanın sonucu olarak yaşam temelli öğretim yaklaşımına dayalı 5E modelinin öğrencilerin ölçme ve değerlendirme dersine karşı tutumlarında ve özyeterlik algı ön test ve son test ortalamalarında istatiksel olarak anlamlı farklılık olduğu belirlenmiştir.

Anahtar Kelimeler: yaşam temelli öğretim yaklaşımı, 5E modeli, ölçme-değerlendirme dersi, tutum, özyeterlik algıSI

\section{Abstract}

The aim of this study was to determine the effect of $5 \mathrm{E}$ model based on context-based instruction approach the attitudes and perception of self-efficacy of pre-service teachers towards the assessment and evaluation course. For this purpose, appropriate contexts for the assessment-evaluation course topics have been prepared and the lessons have been taught in accordance with $5 \mathrm{E}$ model based on context-based instruction approach. The study group consists of 30 students who were studying in the third year of the department of science education in Kilis 7 Aralik University in the spring semester of 2017-2018 academic years. The one-group pre-test post-test pre-experimental designs were utilized as the research method in the study. The application lasted approximately four weeks. Self-Efficacy Perception Scale for Assessment and Evaluation in Education and Self-Efficacy Perception Scale for Assessment and Evaluation in Education were used as the measurement tools. The obtained data were analyzed with dependent groups $t$ test. As a result of the study, it was determined that the $5 \mathrm{E}$ model based on the context-based teaching approach was statistically significant in the attitudes of the students towards the assessment and evaluation course and in the self-efficacy perception pre-test and post-test average.

Keywords: context-based instruction approach, 5E model, assessment and evaluation course, attitudes, perception, self-efficacy

1 Kilis 7 Aralik Universiy, Muallim Rifat Faculty of Education, Department of Mathematics and Science Education, Kilis, Turkey;https://orcid.org/ 0000-0002-3460-3307 Atıf / Citation: Dede, H. (2019). Yaşam temelli öğretim yaklaşımına dayalı 5e modeli kullanımının öğretmen adaylarının ölçme değerlendirme dersine yönelik tutum ve özyeterlik algıları üzerine etkisinin incelenmesi .Kastamonu Education Journal, 27(6), 2547-2558. doi:10.24106/kefdergi.3432 


\section{Extended Abstract}

Assessment and evaluation is required in all of the input, process and product dimensions of the education process (Guler \& Gelbal, 2010). Therefore, it is necessary that all teacher candidates' assessment and evaluation concepts should be internalized before they become involved in the education process as a teacher in order to create effective learning environments (Çalışkan \& Üstündağ, 2010). In addition, pre-service teachers should be able to use some of their special knowledge in the field of assessment and evaluation well enough, develop some skills in this field and have positive attitudes (Turgut \& Baykul, 2012, p.3).

Attitude is the emotional readiness or tendency of individuals to accept or reject a particular person, group, institution, or thought (Baykul, 1990; Özgüven, 1994). In-service and pre-service teachers' affective attitude towards assessment and evaluation is as important as the assessment and evaluation competence (Süral, 2014).

The self-efficacy belief was defined by Bandura (1977) as a sense of personal trust that individuals feel as if they are aware of their current potential and that they can accomplish a task successfully. Individuals' perceptions of self-efficacy on a subject affect many affective situations such as the attitude, motivation and perception of that individual. The studies conducted on this subject show that the high self-efficacy of the teachers enables the teachers to develop their classroom behaviors and positive attitude towards teaching and also positively affect the success and attitude of the students (Başman \& Tavşancıl, 2016; Gibson \& Dembo, 1984; Morgil, Seçken \& Yücel, 2004; Tschannen-Moran, Hoy \& Hoy, 1998).

Previous studies in the field of assessment and evaluation show that the studies carried out in order to determine assessment and evaluation competence, attitudes towards assessment and evalutiaon, the effect of assessment and evaluation tools and opinions of assessment and evaluation (Akdağ, 2011; Akdağ \& Ekmekçi, 2015; Aydın, 2001; Güneş, 2007; Karaca, 2003; Köksal, 2009; Ozan \& Kıncal, 2017; Ulutaş, 2003; Zhang \& Burry-Stock, 2003). Few studies have been found on the effect of the use of modern teaching methods in the assessment and evaluation course (Çalışkan \& Üstündağ, 2010; Demir, 2012).

One of the modern teaching methods is $5 \mathrm{E}$ model. $5 \mathrm{E}$ model is based on a context-based instruction approach. The aim of the context-based instruction approach, which was initially developed as a program development approach based on the constructivist approach, and then became a learning-teaching approach, is to increase the students' desire to learn the subject by giving scientific concepts and subjects through selected contexts from daily life (Barker \& Millar, 1999; Kutu \& Sözbilir, 2011). The 5E teaching model was developed by Bybee (1993) and consists of five stages: Engage, Explore, Explain, Elaborate and Evaluate.

The aim of this study was to determine the effect of $5 \mathrm{E}$ model based on context-based instruction approach the attitudes and perception of self-efficacy of pre-service teachers towards the assessment and evaluation course. For this purpose, appropriate contexts for the assessment-evaluation course topics have been prepared and the lessons have been taught in accordance with $5 \mathrm{E}$ model based on context-based instruction approach. The study utilized single-group pretest-posttest design, which is one of the weak experimental designs. The study group consisted of 30 students in the third year of science education in Kilis 7 Aralik University in the spring semester of 2017-2018 academic years. In order to collect data for the present study, Attitude Scale for Assessment and Evaluation in Education Course (AS-AEEC) and Self-Efficacy Perception Scale for Assessment and Evaluation in Education Course (SEPS-AEEC) were used. The weekly course periods of the assessment and evaluation course were 3 , and the application lasted for 12 course periods. In the study with no control group, the courses for the experiment group were taught in accordance with the $5 \mathrm{E}$ model based on the context-based instruction approach.

Three contexts which were related to statistics, validity and reliability subjects prepared were presented to the students during the engage stage of the course to attract their attention to the subject. During the explore stage of the course, the students were asked to define the definitions of the concepts in the context of the engage stage. In the explain stage of the course, the definitions of the concepts determined by the students are examined, and the defective definitions are corrected and explained. In the elaborate stage of the course, information about the use of the concepts in the context of daily life was given and the open-ended problems were solved with statistical concepts. In the final, evaluate stage of the course, students were asked to solve multiple-choice questions related to concepts.

The significance of the difference between the averages scores of each scale was analyzed by dependent groups $\mathrm{t}$-test, because of the data presented normal distribution. As a result of the study, it was determined that the 5E model based on the context-based teaching approach was statistically significant in the attitudes of the students towards the assessment and evaluation course and in the self-efficacy perception pre-test and post-test average. The literature re-

| Kastamonu Eğitim Dergisi, 27(6), 2019| 
view conducted for the present study on the use of $5 \mathrm{E}$ model showed that the findings of the present study are in agreement with the findings of Sağlam's (2006) and Yalçın's (2010) findings on the attitudes towards science course, Akar's (2005) and Yörük's (2008) findings on the attitudes towards chemistry course, Yalçın, Açışlı and Turgut's (2010) and Bal's (2012) findings on the attitudes towards physics lab course, and Öztürk's (2008) findings on the attitudes towards geography course. It can be claimed that this finding is resulted from students' active participation in the lesson according to context-based instruction approach, which is based on constructivist approach and, the discovery and knowledge of information themselves. Accordingly, we can claim that starting with a context from daily life attracts students' attention to the lesson and that increasing interest has a positive effect on the attitudes towards the course. Another finding of the present study is that, the use of $5 \mathrm{E}$ model based on context-based instruction approach in assessment and evaluation courses increased pre-service teachers' self-efficacy perceptions of assessment and evaluation. This finding is in agreement with the findings obtained in the study conducted by Usta Gezer (2014). It can be claimed that finding was believed to have resulted from the fact that in the elaborate stage of $5 \mathrm{E}$ model, problem-solving environments were created for students, and students solved open-ended questions related to the subject, as students' problem-solving skills develop by solving problems. The more developed the problem-solving skills are, the more self-efficacy perception the students have (Altunçekiç, Yaman, \& Koray, 2005). According to the results of this study, some suggestions were made to the researchers who would like to do similar studies in this area. 


\section{Introduction}

Assessment is the process of observing any attribute and expressing the result of observation with numbers or adjectives, and evaluation is the process of making a value judgment about the measured attribute by expressing the results of the measurement on a criterion or criteria (Turgut \& Baykul, 2012, p.3). Assessment and evaluation is required in all of the input, process and product dimensions of the education process (Guler \& Gelbal, 2010). Therefore, it is necessary that all teacher candidates' assessment and evaluation concepts should be internalized before they become involved in the education process as a teacher in order to create effective learning environments (Çalışkan \& Üstündağ, 2010). In addition, pre-service teachers should be able to use some of their special knowledge in the field of assessment and evaluation well enough, develop some skills in this field and have positive attitudes (Turgut \& Baykul, 2012, p.3). If the teachers are competent in the field of assessment and evaluation, they can facilitate the learning activities, measure the students' learning with the right methods and techniques and make an accurate evaluation. Moreover, the correct assessment and evaluation by the teacher will provide information about not only the success of the students but also the functioning of the education system (Akdağ, 2011).

Attitude is the emotional readiness or tendency of individuals to accept or reject a particular person, group, institution, or thought (Baykul, 1990; Özgüven, 1994). In-service and pre-service teachers' affective attitude towards assessment and evaluation is as important as the assessment and evaluation competence (Süral, 2014).

The self-efficacy belief was defined by Bandura (1977) as a sense of personal trust that individuals feel as if they are aware of their current potential and that they can accomplish a task successfully. Self-efficacy is related to the judgments of individuals about how well they can do the necessary actions to cope with a possible situation (Bıkmaz, 2002). Individuals with low self- efficacy are afraid of taking on challenging tasks and consider these as personal threats. When faced a challenging task, rather than what success they will put, they think of their shortcomings, the obstacles they may face and the bad consequences that may occur (Bandura, 1995, p.11). Individuals with high self-efficacy tend to face challenging tasks as challenges that must be overcome, rather than as threats that should be avoided (Bandura, 1995, p.39). Individuals' perceptions of self-efficacy on a subject affect many affective situations such as the attitude, motivation and perception of that individual. The studies conducted on this subject show that the high self-efficacy of the teachers enables the teachers to develop their classroom behaviors and positive attitude towards teaching and also positively affect the success and attitude of the students (Başman \& Tavşancıl, 2016; Gibson \& Dembo, 1984; Morgil, Seçken \& Yücel, 2004; Tschannen-Moran, Hoy \& Hoy, 1998).

Previous studies in the field of assessment and evaluation show that the studies carried out in order to determine assessment and evaluation competence, attitudes towards assessment and evalutiaon, the effect of assessment and evaluation tools and opinions of assessment and evaluation (Akdağ, 2011; Akdağ \& Ekmekçi, 2015; Aydın, 2001; Güneş, 2007; Karaca, 2003; Köksal, 2009; Ozan \& Kıncal, 2017; Ulutaş, 2003; Zhang \& Burry-Stock, 2003). Few studies have been found on the effect of the use of modern teaching methods in the assessment and evaluation course. For instance, Çalışkan and Üstündağ (2010) used the creative drama method in the assessment and evaluation course and reported that the success, change and development of the teacher candidates' cognitive and affective dimensions varied by using the creative drama method. Demir (2012) used creative drama and Jigsaw II techniques in his assessment and evaluation course and obtained positive opinions from students about the new combined method.

The aim of the context-based instruction approach, which was initially developed as a program development approach based on the constructivist approach, and then became a learning-teaching approach, is to increase the students' desire to learn the subject by giving scientific concepts and subjects through selected contexts from daily life (Barker \& Millar, 1999; Kutu \& Sözbilir, 2011). Since the concepts, contexts and subjects are presented in different directions and relationships, the concepts and subjects are no longer abstract for the students. Therefore, determining or forming the context is very important. When forming the context, it should be ensured that it is selected from the appropriate age level and a situation known to the student. In addition, the context should not be confusing and should not distract the student from the relevant subject and concept (De Jong, 2008).

It is necessary to utilize a suitable teaching model in practicing the context-based instruction approach. According to the related literature, $5 \mathrm{E}$ model is the most frequently used model in context-based instruction approach practices (Kistak, 2014), and there are also studies using REACT strategy (Demircioğlu, Vural, \& Demircioğlu, 2012) and ARCS motivation model (Kutu, 2011). The 5E teaching model was developed by Bybee (1993) and consists of five stages: Engage, Explore, Explain, Elaborate and Evaluate. The model was named after the initials of these 5 stages. Engage stage is the stage where students 'interests are attracted to the subject and the students' prior knowledge is revealed. Explore is 
the stage in which students discover scientific knowledge, at which point the students will experiment with individual or group information, make observations, solve problems and gain experience. Explain is the stage where the teacher is the most active, and they ask the students to share the data from their own experience during the introduction and discovery, and help them to make the necessary explanations to replace the inadequate or inaccurate thoughts with the right ones. Elaborate is the stage where students adapt the new information they learn to different situations and associate them with daily life. Evaluate is the stage in which the teacher helps the students to evaluate their own development, in which they question the new knowledge they have learned. At this stage, while the students are solving the problem, the teacher monitors them and asks them questions (Ayvacı \& Bakırcı, 2012; Bybee, 2002; Krantz, 2004; Şahin \& Çepni, 2012). Studies have shown that the 5E model has a positive effect on students' achievement in the course, their attitudes towards the course, their motivation and self-efficacy. Although it is of critical importance in the education process, there is little emphasis on how the assessment and evaluation course will be taught (Demir, 2012). For this reason, teachers cannot perform sufficient proficiency in the assessment and evaluation process (Karaca, 2003; Tabak, 2007). Teaching of assessment and evaluation course through $5 \mathrm{E}$ model based on the context-based instruction approach is believed to contribute to the training of pre-service teachers positively. Additionally, since there no studies on the teaching of assessment and evaluation course through $5 \mathrm{E}$ model in the national and international literature, findings of the present research is believed to provide important contributions to the literature in terms of the application areas of $5 \mathrm{E}$ model.

\section{Research Problem}

Is the use of a $5 \mathrm{E}$ model based on context-based instruction approach effective on the attitudes of the pre-service teachers towards the assessment and evaluation course and their self-efficacy perceptions?

\section{Sub-problems}

1. Is there a significant difference between pre-service teachers' pre-test and post-test average scores from Attitude Scale for Assessment and Evaluation in Education Course, which measures the attitudes towards assessment and evaluation in education course?

2. Is there a significant difference between pre-service teachers' pre-test and post-test average scores from Self-Efficacy Perception Scale for Assessment and Evaluation in Education Course, which measures the self-efficacy perceptions related to assessment and evaluation in education course?

Assessment and Evaluation, which constitutes one of the four pillars of the curriculum, has an important place in teaching. Every teacher should have a high level of knowledge in the field of assessment and evaluation. However, studies have shown that most of the teachers are not competent enough in the field of assessment and evaluation (Arslantaş, 2011; Gelbal \& Kellecioğlu, 2007; Kilmen \& Demirtaşlı, 2009). The reason for this failure may be the lack of sufficient knowledge in the field of assessment and evaluation, or the lack of self-efficacy or positive attitudes towards assessment and evaluation. It is observed that modern teaching methods and techniques are not used in the assessment and evaluation course. The fact that the present study may define the effects of the use of 5E model based on context-based instruction approach, which is one of the modern teaching methods and techniques, on solving these problems increases the importance of the present study. It is believed that the findings to be obtained at the end of the study will provide a different perspective to the experts and academicians in the field of assessment and evaluation. Moreover, according to the related literature, majority of the studies on contemporary teaching methods are related to the use of these methods in the teaching of major area courses. Since the present study investigates the effects of using modern teaching methods in a pedagogical formation course, rather than a major area course, it is expected to provide great contributions to the related literature.

\section{Method}

\section{Research Design}

The present study utilized single-group pretest-posttest design, which is one of the weak experimental designs. According to this design, experimental procedures are practices on a single group, without a control group. The same measurement tools are applied as pre-test and post-test before and after the application and the measurements for the dependent variable of the subjects in the study group are obtained (Büyüköztürk et al., 2008). Table 1 presents the experimental design applied in the present study. 
Table 1. Experimental design

\begin{tabular}{|c|c|c|}
\hline Pre-test & Experimental Procedure & Post-test \\
\hline $\begin{array}{l}\text { Attitude Scale for Assessment and } \\
\text { Evaluation in Education Course (AS- } \\
\text { AEEC) }\end{array}$ & $\begin{array}{l}\text { 5E Model Based on Context-Based } \\
\text { Instruction Approach }\end{array}$ & $\begin{array}{l}\text { Attitude Scale for Assessment and } \\
\text { Evaluation in Education Course (AS- } \\
\qquad A E E C)\end{array}$ \\
\hline $\begin{array}{l}\text { Self-Efficacy Perception Scale for } \\
\text { Assessment and Evaluation in Edu- } \\
\text { cation Course (SEPS-AEEC) }\end{array}$ & & $\begin{array}{l}\text { Self-Efficacy Perception Scale for } \\
\text { Assessment and Evaluation in Edu- } \\
\text { cation Course (SEPS-AEEC) }\end{array}$ \\
\hline
\end{tabular}

\section{Study Group}

The study group consisted of 30 students in the third year of science education in Kilis 7 Aralik University in the spring semester of 2017-2018 academic years.

\section{Data Collection Tools}

In order to collect data for the present study, Attitude Scale for Assessment and Evaluation in Education Course (AS-AEEC) and Self-Efficacy Perception Scale for Assessment and Evaluation in Education Course (SEPS-AEEC) were used.

\section{Attitude scale for assessment and evaluation in education course (AS-AEEC)}

EÖDDY-TÖ, which is used as pre-test and post-test, was developed by Yaşar (2011) in order to determine the attitudes towards the assessment-evaluation course of the students. The Cronbach's alpha reliability coefficient of the scale consisting of 20 Likert-type items was found as 0.942 . The scale has three sub-dimensions: negative approach (11 items), importance (5 items) and cognitive competence (4) and Cronbach alpha reliability values of these dimensions are $0.93,0.88$, and 0.80 , respectively. In the present study, the Cronbach Alpha reliability coefficient of the pre-test was calculated as 0.86 , and the Cronbach Alpha reliability coefficient of the post-test was calculated as 0.94.

\section{Self-efficacy perception scale for assessment and evaluation in education course (SEPS-AEEC)}

In order to determine the self-efficacy perceptions of the students for the present study, SEPS-AEEC developed by Kılınç (2011) was administered as pre-test and post-test. The 23-item Likert-type scale consists of two sub-dimensions: knowledge-based self-efficacy and skill-based self-efficacy. The Cronbach alpha coefficient of the whole scale was 0.96 while the Cronbach alpha coefficient of the knowledge-based self-efficacy scale was 0.93 and the Cronbach alpha coefficient of the skill-based self-efficacy dimension was calculated as 0.95 . In the present study, the Cronbach's alpha reliability coefficient of the pre-test was 0.94 , and the Cronbach's alpha reliability coefficient of the post-test was calculated as 0.95 .

\section{Scope of the Study and Implementation Process}

The weekly course periods of the assessment and evaluation course were 3 , and the application lasted for 12 course periods. In the study with no control group, the courses for the experiment group were taught in accordance with the $5 \mathrm{E}$ model based on the context-based instruction approach. Before the application, a context was developed for each topic in the scope of the study and the totals of three contexts were prepared. Table 2 presents the titles, the subjects and the concepts of the contexts used in the application.

Table 2. The titles, the subjects and concepts of the contexts used in the application

\begin{tabular}{|c|c|c|}
\hline The Title of Context & The Subject & The Concept \\
\hline Let's See You Find & Statistics & Mode, Median, Mean, Range, Standard Deviation, Standard Score \\
\hline Knowledge Contest & Validity & Conformity validity, Predictive validity \\
\hline The Most Accurate Test & Reliability & $\begin{array}{l}\text { Reliability calculation methods (test half method), Reliability Coefficient, } \\
\text { Factors affecting reliability }\end{array}$ \\
\hline
\end{tabular}

The present study covers three subjects: Statistics, validity and reliability. For the subject of Statistics, the context titled Let's See You Find is prepared. This context includes the concepts of mode, median, mean, range, standard deviation and standard score. In the context, all the concepts to be given in statistics were included. For the subject of Validity, the context titled Knowledge Contest is prepared. This context includes the concepts of conformity validity and predictive validity. In the context, all concepts in the subject of Validity were not included, therefore the description | Kastamonu Eğitim Dergisi, 27(6), 2019| 
of content/scope validity, construct validity, appearance validity and factors affecting validity concepts were given in the explain stage. For the subject of Reliability, the context titled Knowledge Contest is prepared. This context includes the concepts of reliability calculation methods (test half method), reliability coefficient and factors affecting reliability. In the context, all concepts in the subject of Reliability were not included, therefore the description of error in measurement and the other reliability calculation methods concepts were given in the explain stage. The processing of each subject took 4 hours. The implementation process of statistics with 5E Model Based on Context-Based Instruction Approach is summarized below.

The engage stage: The students were asked to read the context of Let's See You Find carefully. In this way, students' attention has been drawn to the subject.

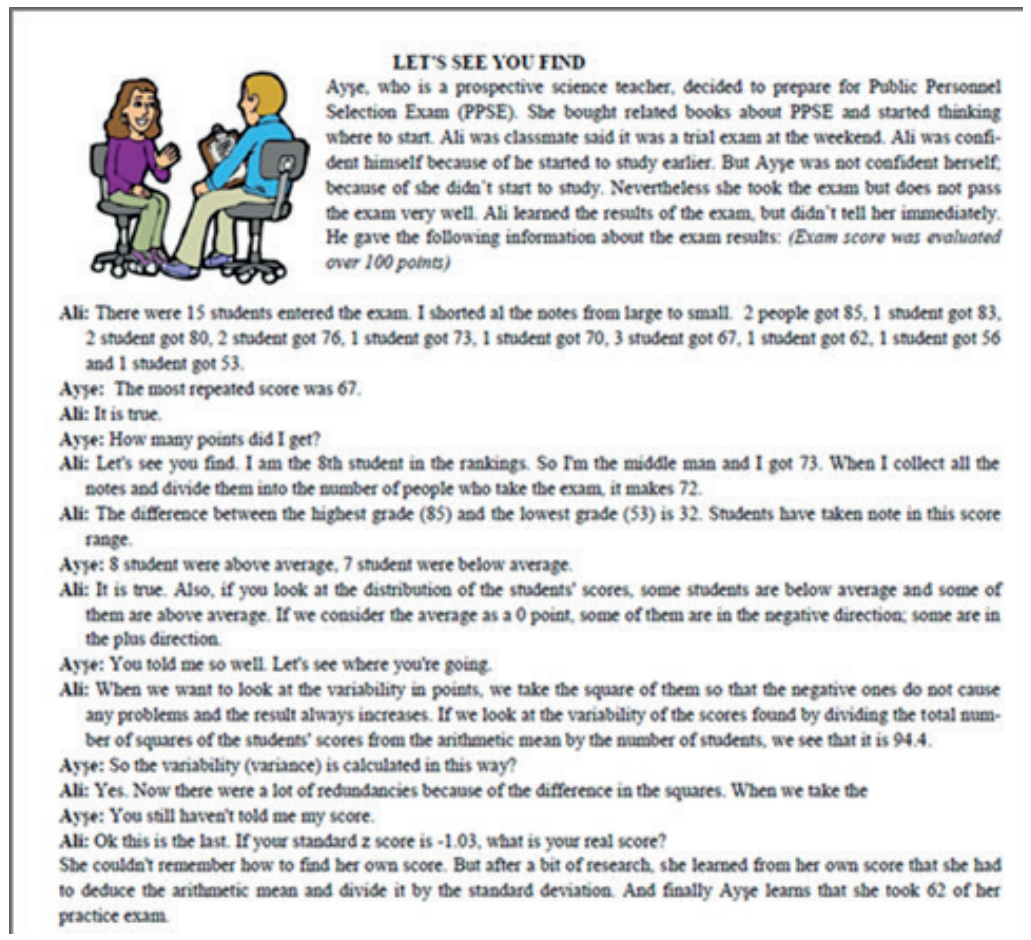

\section{Figure 1. The context used in the engage stage}

The explore stage: At this stage, students were told that each of the calculations in the context belonged to a separate statistical concept and the students were asked to explain what these concepts are and their definitions. The calculations in the context belong to mode, median, mean, range, standard deviation and standard score concepts and students were expected to explore these concepts.

The explain stage: At this stage, the definitions of the concepts determined by the students are examined. In general, it was observed that the students made the concepts of median, mean, standard deviation and their explanations correctly, but they had errors in the mode, range, standard score concept. The defective definitions are corrected and explained.

The elaborate stage: At this stage, information about the use of the concepts in the context of daily life was given and the open-ended problems were solved with statistical concepts. In this way, the new knowledge that the students have learned is adapted to different situations and associated with daily life. 


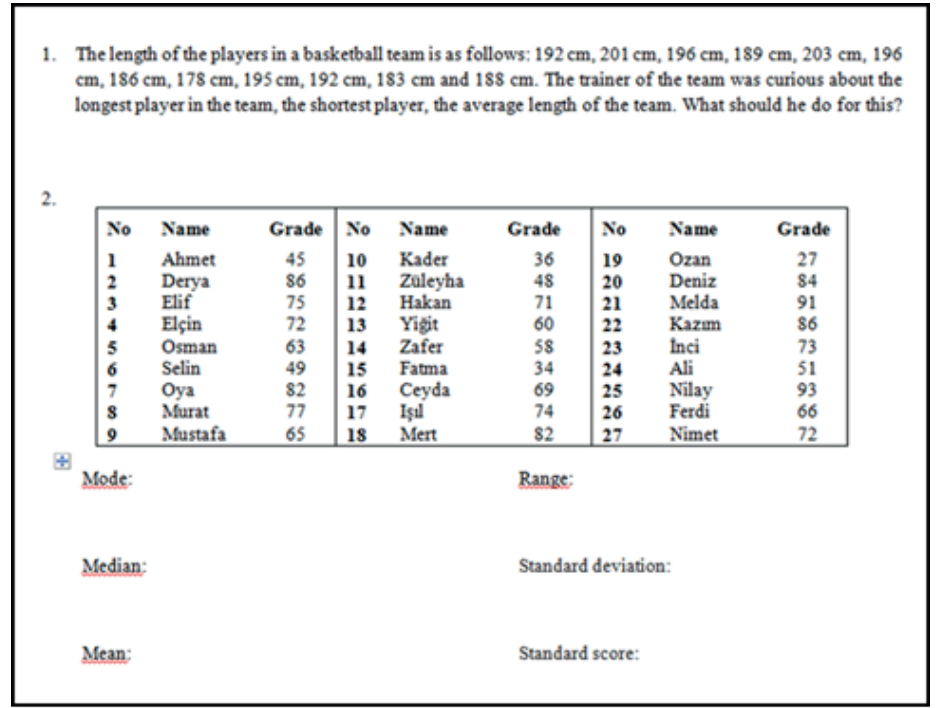

Figure 2. The material used in the elaborate stage

The evaluate stage: At this stage, firstly students were asked to solve multiple choice questions related to the concepts they had recently learned. Then the questions are resolved on the board. In case students made mistakes, the students were given the necessary clues. In this way, the students were helped to reach the correct result.

\section{Data Analysis}

In order to test the first and second sub-problems of the present study, the differences and the standard deviations between the averages of pre-test and post-test scores for AS-AEEC and SEPS-AEEC were calculated. Shapiro-Wilks test was used to determine whether the scores fit the normal distribution as the sample size was smaller than 50 . Since the scores fit the normal distribution, the significance of the difference between the average scores of each scale was analyzed by dependent groups t test (Büyüköztürk, 2009).

\section{Findings}

This part present the findings of the analyses for the data obtained for the present study. The results of the students' pre-test-post-test averages for AS-AEEC and SEPS-AEEC, standard deviation, Shapiro-Wilks and normality test are presented in Table 3.

Table 3. AS-AEEC and SEPS-AEEC pre-test and post-test averages, standard deviation values, shapiro-wilks and normality test results

\begin{tabular}{|c|c|c|c|c|c|c|}
\hline \multirow{2}{*}{ Scales } & & \multirow{2}{*}{$\mathrm{n}$} & \multirow{2}{*}{$\overline{\mathbf{x}}$} & \multirow{2}{*}{ sd } & \multicolumn{2}{|c|}{ Shapiro Wilk } \\
\hline & & & & & Statistic & $p$ \\
\hline \multirow{2}{*}{ AS-AEEC } & Pre-test & 29 & 3.46 & 0.42 & 0.968 & $.513^{*}$ \\
\hline & Post-test & 29 & 3.85 & 0.63 & 0.940 & $1.00 *$ \\
\hline \multirow{2}{*}{ SEPS-AEEC } & Pre-test & 28 & 3.12 & 0.47 & 0.971 & $.602^{*}$ \\
\hline & Post-test & 28 & 3.80 & 0.55 & 0.963 & $.411^{*}$ \\
\hline
\end{tabular}

As presented in Table 3, pre-test and post-test results of attitude and self-efficacy scales fit normal distribution (Shapiro Wilk values are $p>$.05). In Table 4, skewness and kurtosis coefficients for AS-AEEC and SEPS-AEEC pre-test and post-test scores are presented.

Table 4. Skewness and kurtosis coefficients for AS-AEEC and SEPS-AEEC pre-test and post-test scores

\begin{tabular}{llcccc}
\hline & & \multicolumn{2}{c}{ Skewness } & \multicolumn{2}{c}{ Kurtosis } \\
\cline { 3 - 6 } & & Statistic & Standard Error & Statistic & Standard Error \\
\hline \multirow{2}{*}{ AS-AEEC } & Pre-test & -.181 & .434 & -.415 & .845 \\
& Post-test & -.814 & .434 & .439 & .845 \\
\hline \multirow{2}{*}{ SEPS-AEEC } & Pre-test & -.579 & .441 & .070 & .858 \\
& Post-test & -.141 & .441 & .912 & .858 \\
\hline
\end{tabular}

As presented in Table 4, the values of skewness and kurtosis coefficients of the pre-test and post-test scores of both 
AS-AEEC and SEPS-AEEC were between -1 and +1 .

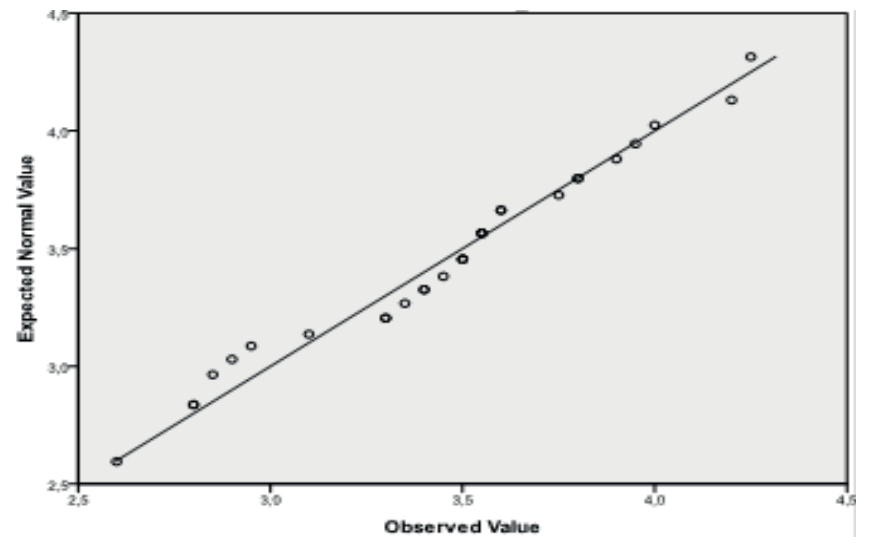

Figure 3. AS-AEEC pre-test q-q plots graph

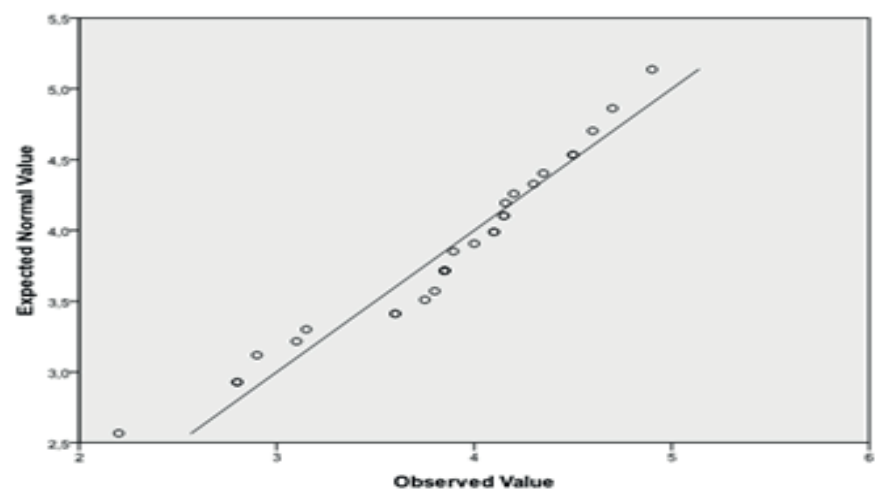

Figure 4. AS-AEEC post-test q-q plots graph

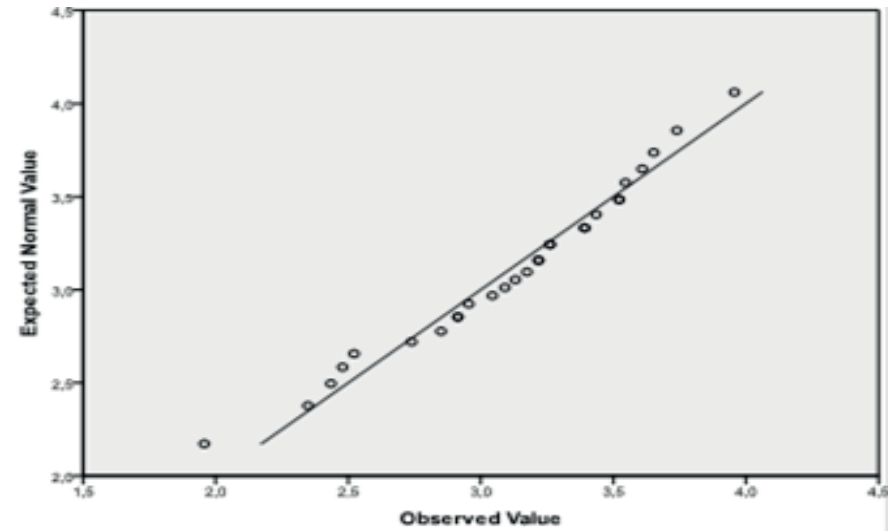

Figure 5. SEPS-AEEC pre-test q-q plots graph

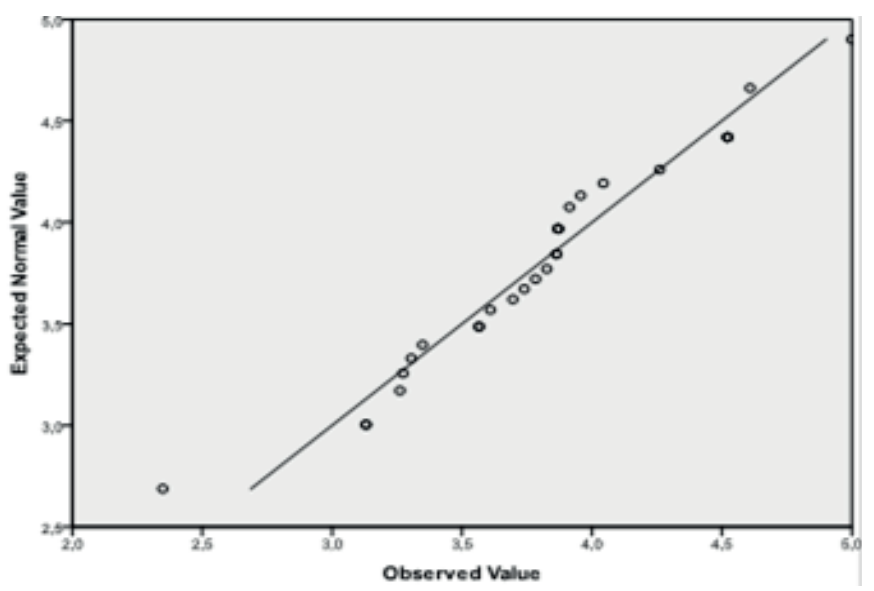

Figure 6. SEPS-AEEC post-test q-q plots graph 
Figures 1, 2, 3 and 4 present q-q plots graphs showing that the pre-test-post-test data of both AS-AEEC and SEPS-AEEC distributed normally. Shapiro Wilk test skewness and kurtosis coefficients and q-q plots graphs were analyzed, and it was found that the data presented normal distribution. For this reason, parametric tests were used for the analysis of the data obtained for the present study (Kalaycı, 2009).

In order to study the effect of $5 E$ model based on context-based instruction approach on the attitudes of pre-service teachers, the significance of the difference between the AS-AEEC pre-test and post-test score averages was tested with dependent groups $t$ test. Table 5 presents the independent groups $t$ test results for pre-test and post-test scores of AS-AEEC.

Table 5. Dependent groups $t$ test results for pre-test and post-test scores of AS-AEEC

\begin{tabular}{lcccccc}
\hline AS-AEEC & $\mathbf{n}$ & $\overline{\mathbf{x}}$ & ss & sd & t & $\mathbf{p}$ \\
\hline Pre-Test & 29 & 3.46 & 0.42 & \multirow{2}{*}{28} & \multirow{2}{*}{-3.486} & \multirow{2}{*}{002} \\
\hline Post-Test & 29 & 3.85 & 0.63 & & & \\
\hline
\end{tabular}

According to dependent groups t-test results of the AS-AEEC pre-test and post-test scores of the students presented in Table 5, there is a statistically significant difference in favor of post-test $(t(29)=-3.486 ; p=0.002 ; p<.05$ ).

Table 6. Dependent groups t test results for pre-test and post-test scores of SEPS-AEEC

\begin{tabular}{lcccccc}
\hline SEPS-AEEC & $\mathbf{n}$ & $\overline{\mathbf{x}}$ & ss & sd & t & $\mathbf{p}$ \\
\hline Pre-Test & 28 & 3.12 & 0.47 & \multirow{2}{*}{27} & \multirow{2}{*}{-5.816} & \multirow{2}{*}{000} \\
\hline Post-Test & 28 & 3.80 & 0.55 & & & \\
\hline
\end{tabular}

According to dependent groups t-test results of the SEPS-AEEC pre-test and post-test scores of the students presented in Table 6 , there is a statistically significant difference in favor of post-test $(t(28)=-5.816 ; p=0.000 ; p<.05)$.

\section{Results and Discussion}

Findings obtained in the present study show that using $5 \mathrm{E}$ model based on context-based instruction approach in assessment and evaluation course positively affects attitudes of pre-service teachers towards assessment and evaluation course. According to the related literature, no studies have been conducted on the effects of $5 \mathrm{E}$ model on the attitudes towards assessment and evaluation course, while there have been several studies on the effects on $5 \mathrm{E}$ model on the attitudes towards science (physics, chemistry, biology, environmental sciences) course. According to the findings of the meta-analysis study conducted by Ayaz (2015) in order to determine the effect of a 5E-learning model on students 'attitudes towards classes, 5E-learning model has a more positive effect on students' attitudes than traditional teaching methods. The literature review conducted for the present study on the use of $5 \mathrm{E}$ model showed that the findings of the present study are in agreement with the findings of Sağlam's (2006) and Yalçın's (2010) findings on the attitudes towards science course, Akar's (2005) and Yörük's (2008) findings on the attitudes towards chemistry course, Yalçın, Açışı and Turgut's (2010) and Bal's (2012) findings on the attitudes towards physics lab course, and Öztürk's (2008) findings on the attitudes towards geography course. It can be claimed that this finding is resulted from students' active participation in the lesson according to context-based instruction approach, which is based on constructivist approach and, the discovery and knowledge of information themselves. Accordingly, we can claim that starting with a context from daily life attracts students' attention to the lesson and that increasing interest has a positive effect on the attitudes towards the course.

Another finding of the present study is that, the use of $5 \mathrm{E}$ model based on context-based instruction approach in assessment and evaluation courses increased pre-service teachers' self-efficacy perceptions of assessment and evaluation. This finding is in agreement with the findings obtained in the study conducted by Usta Gezer (2014). In the study conducted by Usta Gezer (2014), the course of general biology laboratory was carried out using the 5E Model in the experimental group and the traditional method in the control group. According to the findings of the study, a statistically significant difference was found in the self-efficacy average of the students in the experimental group compared to the students in the control group. It can be claimed that finding was believed to have resulted from the fact that in the elaborate stage of $5 \mathrm{E}$ model, problem-solving environments were created for students, and students solved open-ended questions related to the subject, as students' problem-solving skills develop by solving problems. The more developed the problem-solving skills are, the more self-efficacy perception the students have (Altunçekiç, Yaman, \& Koray, 2005).

| Kastamonu Eğitim Dergisi, 27(6), 2019| 
Consequently, according to the findings of the present study, 5E model based on context-based instruction approach has positive effects on pre-service teachers' attitudes towards and self-efficacy perceptions of the assessment and evaluation course. Based on the findings of the present study, following suggestions can be made for researchers who would like to conduct similar studies in the field:

i. Studies on the effect of 5E model based on context-based instruction approach on students' academic achievement, persistence of knowledge, interest and motivation can be conducted.

ii. Reasons for the positive or negative effects of the model can be studied using qualitative data collection tools (interview, observation, etc.).

iii. For the present study, statistics, validity and reliability subjects of assessment and evaluation were taught in accordance with $5 \mathrm{E}$ model based on context-based instruction approach. Further studies can be conducted by teaching other assessment and evaluation subjects in accordance with this model.

\section{References}

Akdağ, G. (2011). Fen ve Teknoloji Öğretmenlerinin Ölçme-Değerlendirmeye ilişkin Yeterlilik Algıları ve Görüşleri (Adıyaman ili Örneği). Yayınlanmamış yüksek lisans tezi, Adıyaman Üniversitesi, Adıyaman.

Akdağ, G. \& Ekmekçi, S. (2015). Fen ve teknoloji öğretmenlerinin ölçme - değerlendirmeye ilişkin yeterlik algıları ve görüşleri. Route Educational and Social Science Journal, 2(3), 253-273.

Altun Yalçın, S., Açışı, S., \& Turgut, Ü. (2010). 5E öğretim modelinin fen bilgisi öğretmen adaylarının bilimsel işlem becerilerine ve fizik laboratuarlarına karşı tutumlarına etkisi. Kastamonu Eğitim Dergisi, 18(1), 147-158.

Altunçekiç, A., Yaman, S., \& Koray, Ö. (2005). Öğretmen adaylarının öz-yeterlik inanç düzeyleri ve problem çözme becerileri üzerine bir araştırma (Kastamonu ili örneği). Kastamonu Eğitim Dergisi, 13(1), 93-102.

Arslantaş, H. İ. (2011). Öğretim elemanlarının öğretim stratejileri-yöntem ve teknikleri, iletişim ve ölçme değerlendirme yeterliklerine yönelik öğrenci görüşleri. Mustafa Kemal Üniversitesi Sosyal Bilimler Enstitüsü Dergisi, 8(15), 487 - 506.

Ayaz M. F. (2015). 5e Öğrenme Modelinin Öğrencilerin Derslere Yönelik Tutumlarına Etkisi: Bir Meta-Analiz Çalışması. Elektronik Eğitim Bilimleri Dergisi, 4(7), 29-50.

Ayvacı, H. Ş. \& Bakırcı, H. (2012). Fen ve teknoloji öğretmenlerinin fen öğretim süreçleriyle ilgili görüşlerinin 5e modeli açısından incelenmesi. Türk Fen Eğitimi Dergisi, 9(2), 132-151.

Bal, E. (2012). 5E Modeli merkezli laboratuvar yaklaşımının fizik laboratuvarı dersinde fen bilgisi öğretmen adaylarının tutum ve başarılarına etkisi. Yayınlanmamış yüksek lisans tezi, Kastamonu Üniversitesi, Kastamonu.

Bandura, A. (1977). Self-efficacy: Toward a unifying theory of behavioral change. Psychological Review, 84(2), 191-215.

Bandura, A. (1995). Exercise of personal and collective efficacy in changing societies. A. Bandura (Yay. Haz.). Self-efficacy in changing societies içinde (s. 1-45). Melbourne, Australia: Cambridge.

Barker, V. \& Millar, R. (1999). Students' reasoning about basic chemical reactions: what changes occur during a context-based post-16 chemistry course? International Journal Science Education, 21(6), 645-665.

Başman, M. \& Tavşancıl, E. (2016). Self-efficacy perceptions and the attitudes of prospective teachers towards assessment and evaluation. International Journal of Social, Behavioral, Educational, Economic, Business and Industrial Engineering, 10(3), 932-937.

Bıkmaz, F. H. (2002). Fen öğretiminde öz-yeterlik inancı ölçeği. Educational Science and Practice, 1(2), 197-210.

Büyüköztürk, Ş. (2009). Sosyal Bilimler İ̧̧in Veri Analizi El Kitabı: Istatistik, Araştırma Deseni SPSS Uygulamaları ve Yorum (9. bs.). Ankara: Pegem Akademi Yayıncilık.

Bybee, R. W. (1993). Instructional model for science education, in developing biological literacy. Colorado Springs, CO: Biological Sciences Curriculum Studies.

Bybee, R. W. (2002). Scientific inquiry, student learning, and the science curriculum. R.W. Bybee (Yay.Haz.). Learning Science and the Science of Learning içinde (s. 25-35). USA: National Science Teachers Association.

Çalışkan, i. Ö. \& Üstündağ, T. (2010). Ölçme ve değerlendirme dersinde yaratıcı dramanın kullanılmasına ilişkin katılımcı görüşleri. Eğitim ve Bilim, 35(155), 36-48.

Çalışkan, H. \& Yazıcı, K. (2013). Ölçme ve değerlendirmeye yönelik tutum ölçeğinin geliştirilmesi ve sosyal bilgiler öğretmenlerinin tutum düzeylerinin çeşitli değişkenlere göre incelenmesi. International Journal of Human Sciences, 10(1), 398-415.

Çoklar, N. A. \& Odabaşı, H. F. (2009). Eğitim teknolojisi standartları açııından öğretmen adaylarının ölçme ve değerlendirme öz yeterliklerinin belirlenmesi. Selçuk Üniversitesi Ahmet Keleşoğlu Eğitim Fakültesi Dergisi, 27, 1-16.

De Jong, O. (2008). Context-based chemical education: how to improve it? Chemical Education International, 8(1), 1-7.

Demir, K. (2012). An evaluation of the combined use of creative drama and Jigsaw II techniques according to the student views: case of a measurement and evaluation course. Procedia-Social and Behavioral Sciences, 47, 455-459.

| Kastamonu Eğitim Dergisi, 27(6), 2019| 
Demircioğlu, H., Vural, S., \& Demircioğlu, G. (2012). "REACT" stratejisine uygun hazırlanan materyalin üstün yetenekli öğrencilerin başarısı üzerinde etkisi. Ondokuz Mayıs Üniversitesi Eğitim Fakültesi Dergisi, 31(2), 101-144.

Erdoğdu, M. Y. (2010, November). Öğretmenlerin ölçme ve değerlendirmeye yönelik tutumlarının bazı değişkenler açısından incelenmesi. International Conference on New Trends in Education and Their Implications, Antalya.

Gelbal, S. \& Kelecioğlu, H. (2007). Öğretmenlerin ölçme ve değerlendirme yöntemleri hakkındaki yeterlilik algıları ve karşılaşttkları sorunlar. Hacettepe Üniversitesi Eğitim Fakültesi Dergisi, 33(33), 135-145.

Gibson, S. \& Dembo, M. H. (1984). Teacher efficacy: A construct validation. Journal of Educational Psychology, 76(4), $569-582$.

Gül, Ş., Yalmancı, S. G., \& Yalmancı, E. (2017). Boşaltım Sistemi Konusunun Öğretiminde React Stratejisinin Etkisi. Kastamonu Üniversitesi Kastamonu Eğition Dergisi, 25(1), 79-96.

Güler, N. \& Gelbal, S. (2010). Açık uçlu matematik sorularının güvenirliğinin klasik test kuramı ve genellenebilirik kuramına göre incelenmesi. Kuram ve Uygulamada Eğitim Bilimleri, 10(2), 991-1019.

Güneş, A. (2007). Sınıf Öğretmenlerinin kendi algılarına göre ölçme ve değerlendirme yeterlikleri. Yayınlanmamış yüksek lisans tezi, Marmara Üniversitesi, İstanbul.

Kalaycı, Ş. (2009). SPSS uygulamalı çok değişkenli istatistik uygulamaları. Ankara: Asil Yayınevi.

Karaca, E. (2003). Öğretmen adaylarının ölçme ve değerlendirme yeterliklerine ilişkin algıları. Yayınlanmamış doktora tezi, Ankara üniversitesi, Ankara.

Kilmen, S. \& Demirtaşlı, N. Ç. (2009). Sınıf öğretmenlerinin ölçme ve değerlendirme ilkelerini uygulama düzeylerine ilişkin görüşleri. Ankara Üniversitesi Eğitim Bilimleri Fakültesi Dergisi, 42(2), 27-54.

Kistak, Ö. (2014). Ilköğretim 8. sınıf fen ve teknoloji dersi” ses" ünitesinin yaşam temelli yaklaşımla öğretimi. Yayınlanmamış yüksek lisans tezi, Balıkesir Üniversitesi, Balıkesir.

Köksal, O. (2009). Yapılandırmacı yaklaşımda 5 e modelini kullanarak ilköğretim ikinci kademe öğrencilerine ingilizce zaman kiplerinin öğretilmesi (7. sınıf). Yayınlanmamış yüksek lisans tezi, Selçuk Üniversitesi, Konya.

Krantz, P.D. (2004). Inquiry, slime and the national standards. Science Activities, 41(3), 22- 25.

Kutu, H. \& Sözbilir, M. (2011). Yaşam temelli ARCS öğretim modeliyle 9. sınıf kimya dersi “Hayatımızda Kimya” ünitesinin öğretimi. Ondokuz Mayıs Üniversitesi Eğitim Fakültesi Dergisi, 30(1), 29-62.

Ozan, C., \& Kıncal, R. Y. (2017). An Investigation of teacher candidates attitudes towards educational measurement in terms of various variables. Turkish Journal of Teacher Education, 6(1), 18-32.

Öztürk, Ç. (2008). Coğrafya öğretiminde 5e modelinin bilimsel süreç becerilerin, başarıya ve tutuma etkisi. Yayınlanmamış doktora tezi, Gazi Üniversitesi, Ankara.

Sağlam, M. (2006). Işık ve ses ünitesine yönelik 5 E etkinliklerinin geliştirilmesi ve etkililiğinin değerlendirilmesi. Yayımlanmamış doktora tezi, Karadeniz Teknik Üniversitesi, Trabzon.

Şahin, Ç. \& Çepni, S. (2012). Effectiveness of instruction based on the 5e teaching model on students' conceptual understanding about gas pressure. Necatibey Eğitim Fakültesi Elektronik Fen ve Matematik Eğitimi Dergisi, 6(1), 220-264.

Tabak, R. (2007). Illköğretim 5. sınıffen ve teknoloji ders programının öğrenme - öğretme ve ölçme değerlendirme yaklaşımları kapsamında incelenmesi (Muğla ili örneği). Yayınlanmamış yüksek lisans tezi, Muğla Üniversitesi, Muğla.

Tschannen-Moran, M., Woolfolk-Hoy, A., \& Hoy, W. K. (1998). Teacher efficacy: Its meaning and measure. Review of Educational Research, 68(2), 202-248.

Turgut, M.F. \& Baykul, Y. (2012). Eğitimde ölçme ve değerlendirme. Ankara: Pegem Akademi.

Usta Gezer, S. (2014). Yansıtıcı sorgulamaya dayalı genel biyoloji laboratuvarı etkinliklerinin fen bilgisi öğretmen adaylarının laboratuvar kullanımı özyeterlik algıları, eleştirel düşünme eğilimleri ve bilimsel süreç becerileri üzerine etkisi. Yayınlanmamış doktora tezi, Marmara Üniversitesi, Ankara.

Yalçın, E. (2010). 5E öğrenme yönteminin 8. sını öğrencilerinin yaşamımızdaki elektrik konusunu anlamalarına ve fene yönelik tutumlarına etkisi. Yayımlanmamış yüksek lisans tezi, Sakarya Üniversitesi, Sakarya.

Yörük, N. (2008). Kimya Öğretiminde 5e öğrenme modeline dayalı fen, teknoloji, toplum ve çevre (FTÇÇ) yaklaşımının etkisi. Yayınlanmamış doktora tezi, Hacettepe Üniversitesi, Ankara.

Zhang, Z. \& Burry-Stock, J. A. (2003). Classroom assessment practices and teachers' self- perceived assessment skills. Applied Measurement in Education, 16 (4), 323-342. 